УДК.621.314

Yu. Baidak ${ }^{1 凶}$, V. Matukhno ${ }^{2}$, V. Chaikovskiy ${ }^{2}$

${ }^{1}$ Odessa National Academy of Food Technologies, 112 Kanatnaya st., Odessa, 65039, Ukraine

$\triangle$ e-mail: kozak_admin@ukr.net, ORCID: http://orcid.org/0000-0001-7594-0564

${ }^{2}$ Odessa National Polytechnic University, 1 Shevchenko av., Odessa, 65044, Ukraine

\title{
ENERGY EFFICIENT TRANSFORMERS WITH VARIOUS LOAD GRAPHICS FOR THE CONSUMERS OF ELECTRIC POWER
}

The development and implementation of a new economic electrical equipment, in particular, energyefficient distribution transformers - is a very essential step to reduce electricity losses in 0,4-35kV distribution networks. In a market economy the funds invested into the sector of energetics provide maximum profit to the joint stock company only in the case of the production profitability. In such a situation it is possible to achieve optimal material and energy costs on the transformation of power only under the condition of taking into account such factors as load charts of electricity consumption, the cost of the electrical power losses and maintenance of transformers in the process of exploitation, etc. Existing until today practice of transformers design ignores the actual characteristics of individual customers load charts that results in inefficient use of power transformers capacities during their operation. Non-consideration of the electroconsumer actual operating mode (load curve) in the design period leads to inefficient use of transformer capacity. It is proposed for a tight load schedule to design the transformer for the nearest least normalized power compared to the actual load, providing the possibility of intensification of cooling in case of power consumption increasing.

Key words: Transformer; Power consumption; Load; Capacity; Distribution networks.

\author{
Ю. В. Байдак ${ }^{1}$, В. А. Матухно ${ }^{2}$, В. П. Чайковський ${ }^{2}$ \\ ${ }^{1}$ Одеська національна академія харчових технологій, вул. Канатна, 112, Одеса, 65039, Україна \\ ${ }^{2}$ Одеський національний політехнічний університет, пр. Шевченка, 1, Одеса, 65044, Україна
}

\section{ЕНЕРГОЕФЕКТИВНІ ТРАНСФОРМАТОРИ ДЛЯ ЕЛЕКТРОСПОЖИВАЧІВ 3 РІЗНИМИ ГРАФІКАМИ НАВАНТАЖЕННЯ}

Неврахування при проектуванні дійсного режиму роботи (графіка навантаження) електроспоживачів призводить до неефективного використання трансформаторної потужності. Пропонується при поганому графіку навантаження спроектувати трансформатор на найближчу меншу нормалізовану потужність у порівнянні з реальним завантаженням, при иььому передбачити можливість інтенсифікації охолодження при збільшенні споживаної потужності.

Ключові слова: Трансформатор; Споживання енергї̈; Навантаження; Місткість; Розподільні мережі.

This work is licensed under the Creative Commons Attribution International License (CC BY). http://creativecommons.org/licenses/by/4.0/

\section{INTRODUCTION}

The development and implementation of a new economic electrical equipment, in particular, energy-efficient distribution transformers - is a very essential step to reduce electricity losses in $0,4-35 \mathrm{kV}$ distribution networks.

In a market economy the funds invested into the sector of energetics provide maximum profit to the joint stock company only in the case of the production profitability. In such a situation it is possible to achieve optimal material and energy costs on the transformation of power only under the condition of taking into account such factors as load charts of electricity consumption, the cost of the electrical power losses and maintenance of transformers in the process of exploitation, etc.
Existing until today practice of transformers design ignores the actual characteristics of individual customers load charts that results in inefficient use of power transformers capacities during their operation.

Only recently some companies which manufacture transformers have begun to adhere to the principle of customization, which takes into account the requirements of a particular user (Kravchenko, 2013) [5].

Today's situation with the irrational utilization (mostly under-utilization) of transformer capacity can be explained by "operational" (e.g, industrial facilities like power consumers are in a stage of stagnation, etc.) and "design" (the wrong accounting of nominal load losses time of the transformer that was laid down in the design process) reasons. 
For the rational utilization of transformers which are already in operation, if the actual loads do not match with the project ones (real load is generally less) it is necessary to replace the operating transformer on the lower power transformer without changing the cooling system.

Proper tracking of nominal load losses time at the transformer design stage will allow to increase the efficiency of its operation. Neglect of real operating conditions of customers at the design stage leads to damage associated either with overspending of investment (if the load is lesser than project one), or to the additional costs of electricity losses (if the load is more than the project one).

According to $[1,7,11]$, it is possible to determine the number of shifts on the enterprise using the annual consumers operation number of hours with maximum load and annual energy consumption. The exploitation time interval of the transformer with a rated capacity is equal to $1800 \ldots 2500$ (load factor $F_{1}=(0.2 \ldots 0.3)$ for one-shift work, for two-shift work $-3500 \ldots 4500$ $\left(F_{1}=0.4 \ldots 0.5\right)$, for three-shift work $-5000 \ldots 7000$ $\left(\mathrm{F}_{1}=0.55 \quad \ldots \quad 0.8\right)$. The modern series of distribution transformers of 1 and 2 dimensions is designed for average operational loads, typical for two-shift production schedule [10].

The main characteristics that define the technical and economic level of power transformers are power losses (of no-load operation and short-circuit). Levels of these losses, their relationship, characterize the operation mode of electric consumers.

One possible way of rational utilization of distribution transformers $[7,12]$ is the development of a series of transformers with different ratios of the no-load operation and short-circuits losses values. However, this path leads to the creation of an excessively large number of distribution transformers modifications.

In $[6,8]$ it was noted that for a small-time operation of a distribution transformer with a rated load it is necessary to use the transformer with a lesser capacity in order to save material and energy resources, providing for intensification of cooling in case of the transformer operation on a heavier load.

Computational studies has shown that for increasing the effect of the implementation in practice this type of distribution transformers it would be useful to introduce the intermediate sizes (power) transformers in modern domestic standard power ratings. This will create a series of distribution transformers with a scale pitch equal to 1.25 of the scale capacity used in the standard international practice [12]. Aligning national standards in line with the Harmonization Documents - HD which are the basis for the EN - European standard, which is required for a single European settlement of the issues of transformer is the actual task [13].

\section{MATERIALS AND METHODS}

In the framework of this article computational studies to determine the effectiveness of the use of the transformer, depending on the characteristics of the technological mode (shift) of the electroconsumer work were con- ducted, necessary measures were determined for the rehabilitation of existing cooling systems through the use of additional oil coolers.

The criterion of discounted expenses was adopted at the design studies to assess the effectiveness of the technical solutions. These are the expenses on construction and exploitation of the transformer, considering the inflation processes in the economy, from the moment of determining the expenses for the whole period of operation $[4,9]$.

$$
3_{\partial}=D_{\text {ЭКв.Т }} \cdot K_{T P}+C_{x x} \cdot P_{x x}+\left(\frac{P_{\kappa 3}}{U_{\mathrm{H}}^{2}}\right) \cdot S^{2}, U A H,
$$

where

$D_{\text {ЭКВ.Т }}=(1+E)^{-1}+a_{\text {обсл }} \cdot D_{\text {РЭ }}-\left(1-a_{\text {рен }} \cdot T_{\ni}\right) \cdot(1+E)^{-T_{P}}-$ equivalent discount factor;

$D_{P \ni}=\sum_{\mathrm{t}=1}^{T_{P}}(1+E)^{-t}-$ estimated discount factor for the period of operation until the end of the estimated period;

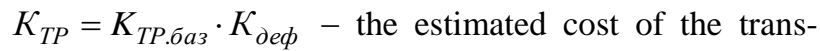
former considering the inflation factor at the time of determination of expenses.

$a_{\text {обсл }}-$ coefficient of royalties for service and repair;

$a_{p e r}-$ coefficient of royalties for renovation;

$T_{\text {э }}$ - operation period of the transformer;

$E$ - standard of discounting;

$T_{p}$ - duration of the calculation period;

$C_{x x}=C_{e} \cdot T_{в} \cdot D_{\text {рэ. }}-$ expenses on compensation for loss in the mode of idling;

$C_{e}$ - electricity price;

$T_{B}$ - transformer activation time.

In carrying out these studies economic such economic parameters were adopted: standard of discounting $=0,1$; calculation duration period $=10$ years; deflation rate at the 2014 year level $=30$; the price of electricity $=1,80 \mathrm{UAH} /(\mathrm{kW} \cdot$ year $)$.

As an example, two distribution transformers with adjacent capacity (increments of the scale were equal to 1,25$)$ which are used today in generally accepted international practice were considered. Transformer operation at the less power in the modes in which the currents flowing in the windings of the transformer are commensurate with transformer currents of greater power, is accompanied by a significant increase in current density in the windings and thus increasing the level of losses in the transformer approximately on $25-35 \%$. [8]

Increase in the level of total losses for the transformer of less capacity running with a load close to the nominal of the higher power transformer (adjacent on power scale) in turn leads to higher winding temperatures and consequently to the need in performing technical measures aimed at maintaining the thermal state of the transformer within rules laid down in $[2,3]$.

The most appropriate way to intensify the cooling (forcing) is the connection of additional cooling devices to an existing cooling system. This is explained by the 
fact that the industry has mastered the production of radiators with any number of cooling tubes. With proper selection of the number of cooling pipes in the radiators it is always possible to achieve the required degree of cooling boost.

The cost of the transformer is the sum of the values of the active part and the cost of the cooling system:

$$
Ц_{T P}=Ц_{a .4 .}+Ц_{o x л}
$$

Additional financial expenses for intensification of cooling are determined according to the expression:

$\Delta \bigcup_{\Phi}=\left(P_{X X 2}-P_{X X 1}\right) \cdot T_{B} \cdot C_{\ni}+\left(P_{K 32} \cdot \tau_{2} \cdot C_{\ni}-P_{K 31} \cdot \tau_{1} \cdot C_{\ni}\right)$

where $P_{X X 2}, P_{K 32}$ - losses levels (respectively idling and short circuit) of the transformer with a less magnitude capacity than the actual operating load, $\mathrm{kW}$;

$P_{X X 1}, P_{K 31}$ - losses levels (respectively idling and short circuit) of the transformer with equal to or greater magnitude capacity than the actual operational load, $\mathrm{kW}$;

$T_{B}$ - transformer activation time, hours;

$\tau_{1}, \tau_{2}$ - transformer operation time at the nominal load, respectively of higher and lower capacity;
$C_{\text {э }}$ - the price of electrical power, $\mathrm{UAN} / \mathrm{kw} \cdot \mathrm{hour}$.

In turn the cost of the cooling system

$$
\zeta_{\text {oxл }}=C_{\text {oxл }} \cdot\left(P_{K 3}+P_{X X}\right)
$$

where $C_{\text {охл }}$ - specific cost of losses compensation.

In the market conditions the transformer cooling devices production cost from different manufacturers of transformer equipment may vary by $20-30 \%$. In order not to become attached to the cost indexes of a specific producer maximum values of $C_{\text {охлмах }}$ cooling devices specific cost were determined, to compensate the increase in the transformer total losses (at the loads in magnitude of transformer higher nominal power).

The maximum values of additional cooling devices specific cost - i.e. the limit values at which the production and operation expenses of the less power transformers are the same with high power transformer without additional cooling devices. In high load conditions due to the use of additional cooling devices the lifetime of insulating materials remains unchanged.

The results of computational experiment for one pair of adjacent power transformers are given in Table 1.

Table 1 - Technical and economic parameters of the less power transformer when it is operating with the relevant high-

\begin{tabular}{|c|c|c|c|c|c|c|c|c|}
\hline \multirow{3}{*}{$\begin{array}{l}\text { Technical } \\
\text { and economic } \\
\text { parameters }\end{array}$} & \multirow{3}{*}{$\begin{array}{c}S_{H}=320 \\
\mathrm{kV} \cdot \mathrm{A}\end{array}$} & \multicolumn{6}{|c|}{$\begin{array}{c}\text { Geometry } S_{H}=320 \mathrm{kV} \cdot \mathrm{A} . \text { Load (currents) } S_{H}=400 \mathrm{kV} \cdot \mathrm{A} ; \\
\text { Steel }(3406)=15 \mathrm{UAH} / \mathrm{kg} ; \text { Copper }=60 \mathrm{UAH} / \mathrm{kg} \\
\text { The load of higher power transformer }(\text { operation mode })\end{array}$} & \multirow{3}{*}{$\begin{array}{c}S_{H}=400 \\
\mathrm{kV} \cdot \mathrm{A}\end{array}$} \\
\hline & & \multicolumn{2}{|c|}{ one-shift } & \multicolumn{2}{|c|}{ two-shift } & \multicolumn{2}{|c|}{ three-shift } & \\
\hline & & 0,2 & 0,3 & 0,4 & 0,5 & 0,6 & 0,65 & \\
\hline $\mathrm{MO}, \mathrm{mm}$ & 323 & 323 & 323 & 323 & 323 & 323 & 323 & 333 \\
\hline $\mathrm{D}, \mathrm{mm}$ & 165 & 165 & 165 & 165 & 165 & 165 & 165 & 175 \\
\hline $\mathrm{H}, \mathrm{mm}$ & 520 & 520 & 520 & 520 & 520 & 520 & 520 & 552 \\
\hline $\mathrm{U}_{\mathrm{k}}, \%$ & 4,5 & 5,78 & 5,78 & 5,78 & 5,78 & 5,78 & 5,78 & 4,5 \\
\hline $\mathrm{G}_{\mathrm{CU}}, \mathrm{kg}$ & 278 & 278 & 278 & 278 & 278 & 278 & 278 & 310 \\
\hline $\mathrm{G}_{\mathrm{MA}}, \mathrm{kg}$ & 450 & 450 & 450 & 450 & 450 & 450 & 450 & 523 \\
\hline $\mathbf{3}_{д}$, UAH/year & 7440 & 6585 & 7042 & 7499 & 7955 & 8440 & 8615 & 8618 \\
\hline $\mathbf{C}_{\text {a.ч. }}, \mathrm{UAH}$ & 24244 & 24244 & 24244 & 24244 & 24244 & 24244 & 24244 & 27333 \\
\hline $\mathrm{P}_{\mathrm{K} 3}, \mathrm{~W}$ & 4458 & 6925 & 6925 & 6925 & 6925 & 6925 & 6925 & 5557 \\
\hline $\mathrm{P}_{\mathrm{XX}}, \mathrm{W}$ & 709 & 709 & 709 & 709 & 709 & 709 & 709 & 826 \\
\hline $\mathrm{P}_{\mathrm{K} 3 /} \mathrm{P}_{\mathrm{XX}}, \mathrm{W}$ & 6,29 & 9,77 & 9,77 & 9,77 & 9,77 & 9,77 & 9,77 & 6,72 \\
\hline $\mathrm{J}_{\mathrm{HH}} / \mathrm{J}_{\mathrm{BH}}, \mathrm{A} / \mathrm{mm}^{2}$ & 2,75 & 3,35 & 3,35 & 3,35 & 3,35 & 3,35 & 3,35 & 2,8 \\
\hline & $\overline{2,25}$ & $\overline{2,85}$ & $\overline{2,85}$ & $\overline{2,85}$ & $\overline{2,85}$ & $\overline{2,85}$ & $\overline{2,85}$ & $\overline{2,45}$ \\
\hline $\mathrm{t}_{\mathrm{HH}} / \mathrm{t}_{\mathrm{BH}},{ }^{\circ} \mathrm{C}$ & 16,7 & 22,4 & 22,4 & 22,4 & 22,4 & 22,4 & 22,4 & 17,6 \\
\hline & $\overline{16,1}$ & $\overline{22,5}$ & $\overline{22,5}$ & $\overline{22,5}$ & $\overline{22,5}$ & $\overline{22,5}$ & $\overline{22,5}$ & $\overline{17,7}$ \\
\hline $\mathrm{P}_{\text {сум }}=\mathrm{P}_{\mathrm{XX}}+\mathrm{P}_{\mathrm{K} 3}, \mathrm{~W}$ & 5167 & 7634 & 7634 & 7634 & 7634 & 7634 & 7634 & 6383 \\
\hline $\begin{array}{l}\Delta \text { Рсум }=\mathrm{P}_{\text {сум } 320-} \\
\mathrm{P}_{\text {сум } 400}, \mathrm{~W}\end{array}$ & & 1251 & 1251 & 1251 & 1251 & 1251 & 1251 & 0 \\
\hline $\begin{array}{l}\Delta 3_{\text {д }}=3_{\text {д } 320^{-}} 3_{\text {д } 400}, \\
\text { UAH/year }\end{array}$ & & -2033 & -1576 & -1119 & -663 & -178 & -3 & 0 \\
\hline $\mathrm{C}_{\text {охл }}\left(3_{\text {д }}\right)_{\text {мах }}, \mathrm{UAH} / \mathrm{kW}$ & & 1625 & 1260 & 895 & 530 & 143 & 2 & \\
\hline $\mathrm{n}_{\text {охл }}$ & 2 & & & & 3 & & & 3 \\
\hline $\mathrm{t}_{\text {мac }},{ }^{\circ} \mathrm{C}$ & 38,4 & & & & 1,7 & & & 35,8 \\
\hline$\Delta \mathrm{K}, \mathrm{UAH}$ & & & & & 96 & & & \\
\hline $\mathrm{C}_{\text {охл действ }}, \mathrm{UAH} / \mathrm{kW}$ & & & & & 16 & & & \\
\hline
\end{tabular}
er power transformer loads 
Graphic interpretation of computational research is shown in Figure 1 as a function $C_{\text {охлмах }}=f\left(S_{\mathrm{H}}, K_{3}\right)$. According to this relationship we can determine the maximum value of the specific value $(\mathrm{UAH} / \mathrm{kW})$ of additional cooling devices for a given power transformer and its operation mode (shift), in which the manufacture and operation of power transformers related costs will be the same.

In view of the prices $[14,15]$ of structural steel $(8 \mathrm{UAH} / \mathrm{kg})$ and transformer oil $(15 \mathrm{UAH} / \mathrm{kg})$ of addi- tional capital investments for the cooling intensification are $\Delta K=\bigsqcup_{\text {стохл }} \cdot G_{\text {стохл }}+\bigsqcup_{\text {мохл }} \cdot G_{\text {мохл }}$ for radiators with the following distance between flanges:

$710 \mathrm{~mm}: \Delta K_{710}=8 \cdot 34,14+15 \cdot 24=585,12 \approx 586 \mathrm{UAH}$;

$900 \mathrm{~mm}: \Delta K_{900}=8 \cdot 41,14+15 \cdot 30=719,12 \approx 720 \mathrm{UAH}$;

$1150 \mathrm{~mm}: \Delta K_{1150}=8 \cdot 50,14+15 \cdot 38=895,12 \approx 896 \mathrm{UAH}$;

$1400 \mathrm{~mm}: \Delta K_{1400}=8 \cdot 53,94+15 \cdot 46=1029,52 \approx 1030 \mathrm{UAH}$.

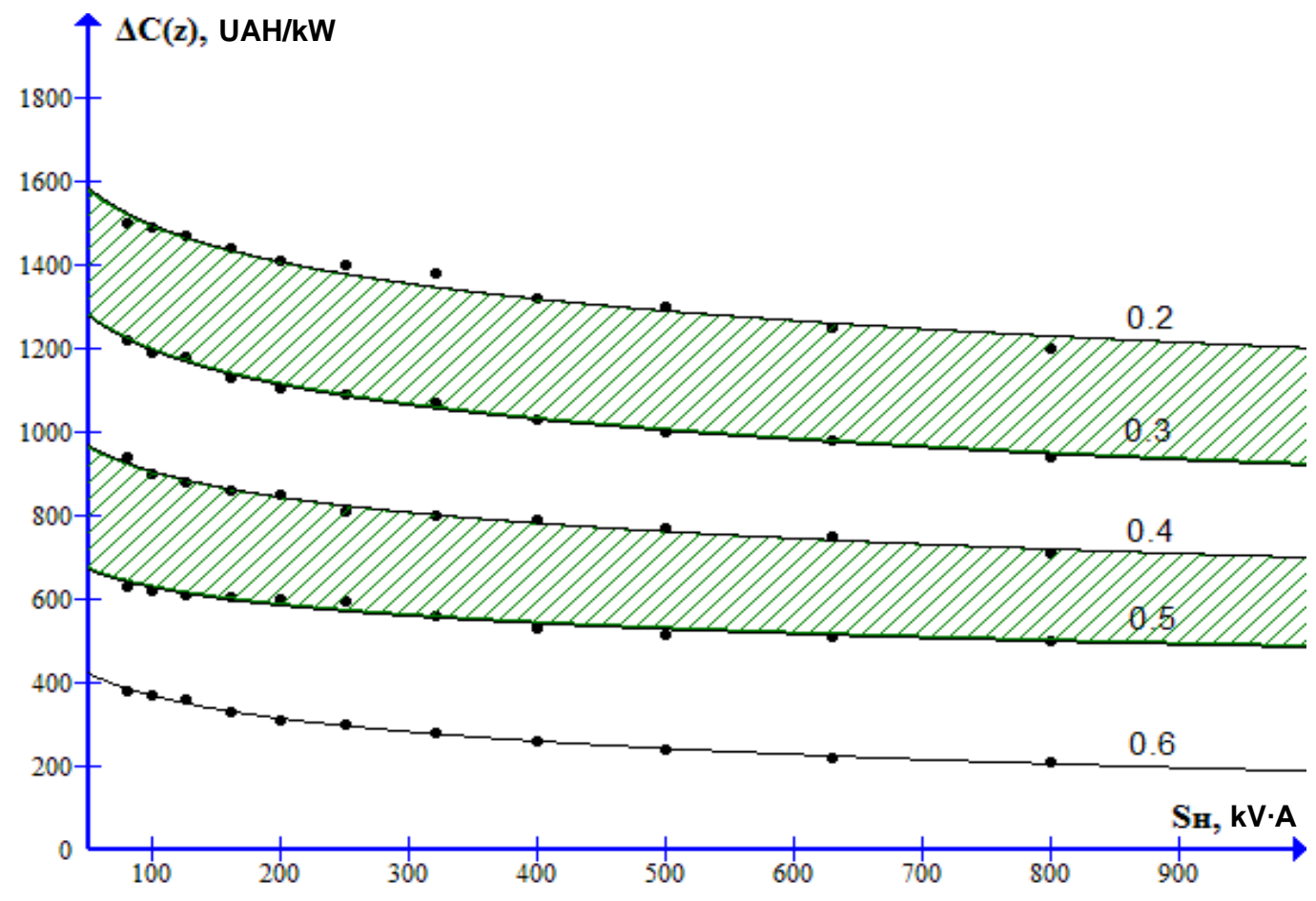

Figure 1 - Values ranges of the specific cost of additional cooling devices, which provide economic benefit from the use of transformers.

The analysis the catalog data of different manufacturers of transformer equipment shows that the weight of the transformer oil in tanks of adjacent power transformers differs by about 20-30 kilograms (with a power range $S_{\mathrm{H}}=100-500 \mathrm{kVA}$ ) and 30-80 kilograms (with a power range $S_{\mathrm{H}}=500-1000 \mathrm{kVA}$ ). This allows you to obtain additional economic benefit of $E_{\mathrm{D}}=(20 . .30) \cdot 15=$ $(300 \ldots 450) \mathrm{UAH}$, at a power transformer $S_{\mathrm{H}}=100$ $500 \mathrm{kWA}$ и $E_{\text {Д }}=(30 \ldots 80) \cdot 15=(400 . .900) \mathrm{UAH}$, at a transformer power $S_{\mathrm{H}}=500-1000 \mathrm{kVA}$.

\section{RESULTS AND DISCUSSION}

1. To create energy-efficient transformers with optimum technical and economic parameters it is necessary at the design stage follow the principle of customization, which takes into account features of the schedule loads and requirements of specific electroconsumer for which they are being developed.
2. Standard or specific graphs of loads should be the basis for determining the optimal technical and economic parameters of transformers. Neglect in the design of the actual operating mode (load curve) of electroconsumer leads to inefficient use of transformer capacity.

3. The underutilization of transformer capacity by load loss requires the use of lower power transformers in comparison with the actual load and the use of intensification (boost) when the transformer cooling modes with power consumption higher than the nominal value.

4. The series of transformers produced today with a sufficiently large pitch (about 1.6) on a scale rated power does not allow the use of a transformer at rated power (of the two adjacent row on the normalized power) at the actual load of power consumer for (25-30)\% less than the nominal capacity of the higher power transformer.

5. It is proposed the approach to the original design and the use of transformers with reduced power (on the normalized row) compared with the actual load and the more intensive use of the cooling system during operation of the transformer in nominal mode corresponding to the 
nearest greater capacity on the normalized row, and in an overload mode .

6. To increase the effect of the introduction into practice this activity it is expedient to introduce the intermediate sizes of (power) transformers into the modern national standard of power ratings with 1.25 increment. This will allow to introduce the power scale, applied currently abroad.

\section{REFERENCES}

1. Bystritskiy, G.F. (2003). Vybor i ekspluatatsiia silovyh transformatorov. Moskow, Izdatelskiy tsentr «Akademiya», $176 \mathrm{p}$.

2. GOST 14209-97(MEK 354-91). Mezhgosudarstvennyiy standart. Rukovodstvo po nagruzke silovyh maslianyh transformatorov. (Data vvedeniia 2002.01.01).

3. DSTU 3645-97 (GOST 3484.2-88) (IEC 600762:1993) Transformatori silovi. Dopustymi perevyschennia temperatury ta metody vyprobuvannia na nagrivannia.Chinniy vId 2000-07-01, 35 p.

4. Zuev, E.N. (2002). K voprosu ob aktualizatsii normativov na ekonomicheskuiu plotnost toka. Elektro, No. 6.

5. Kravchenko, A.N., Metelskiy, V.P. (2013). Maslianyie energoeffektivnyie transformatory. Elektrik, No. 5.

6. Matuhno, V.A. (2009). Designing transformers according to their exploitation load. Electrical machinebuilding and electrical equipment, iss. 73, 97-101.

7. Pekelis, V.G. Myishkovets, E.V., Leus, Yu.V. (2003). Opredelenie optimalnyh urovnei poter kholostogo khoda i korotkogo zamykaniia dlia razlichnyh rezhimnyh usloviy raboty transformatorov moschnostiu do $1600 \mathrm{kVA}$. Elektro, No. 1, 42-46.

8. Puylo, G.V., Chaykovskiy, V.P., Matuhno, V.A. (2013). Seriia optimalnykh transformatorov dlia elektropotrebitelei s razlichnymi grafikami nagruzki. Nauka v Informatsiynomu prostori: IX int. scien. conf. (10-11
October 2013), URL: http://www.confcontact.com/2013nauka-v-informatsionnom-prostranstve/tn6_pujlo.htm.

Date of access: 02.02.2016.

9. Savintsev, Yu.M., Karamutdinov, R.N. (2010). Vybor silovogo transformatora - delo serioznoie [Electronic source]. Available at: http://www.energyland.info/analiticshow-56794. Date of access: 02.02.2016.

10. Tihomirov, P.M. (1986). Raschet transformatorov. Moskow, Energoatomizdat, $528 \mathrm{p}$.

11. Shidlovskiy, A.K., Vagin, G.Ya.,. Kurennyiy, E.G. (1992). Raschety elektricheskih nagruzok sistem elektrosnabzheniia promyshlennykh predpriiatiy. Moskow, Energoatomizdat, $224 \mathrm{p}$.

12. Energosberezhenie v Evrope: primenenie energoeffektivnyih raspredelitelnyih transformatorov [izdanie Evropeyskogo instituta medi (Tema «B» sovmestno s Evropeyskoy Komissiey proekta No. STR-1678-98-BE), per. s angl. E. V. Melnikova]. Energosberezhenie, 1'2004. Available at: http://www.abok.ru/for_spec/articles.php? nid=2384. Date of access: 02.02.2016.

13. HD 428 (Harmonization Documents): Trekhfaznyie raspredelitelnyie transformatory $\mathrm{s}$ rabochei chastotoi $50 \mathrm{~Hz}$ ot 50 do $2500 \mathrm{kV} \cdot \mathrm{A}$ s maslianym okhlazhdeniem i maksimalnym napriazheniem ne vyshe $36 \mathrm{kV}$. [Electronic source]. Available at: http://www.abok.ru/for_spec/articles.php?nid=2384. Date of access: 02.02.2016.

14. Stali i splavyi korrozionno-stoykie i spetsialnyie v Ukraine [Electronic source]. Available at: http://www.ua.all.biz/stali-i-splavy-korrozionno-stojkie-ispecialnye-bgr1553]. Date of access: 02.02.2016.

15. Transformatornyie masla [Electronic source]. Available at: ttp://odessa.pulsen.com.ua/price/040119-transformatornye-masla. Date of access: 02.02.2016.

Received 23 December 2015

Approved 03 March 2016 Available in Internet 29 April 2016

\footnotetext{
Ю. В. Байдак ${ }^{1}$, В. А. Матухно ${ }^{2}$ В. П. Чайковский ${ }^{2}$

${ }^{1}$ Одесская национальная академия пищевых технологий, ул. Канатная, 112, Одесса, 65039, Украина

$\bowtie$ e-mail: kozak_admin@ukr.net, ORCID: http://orcid.org/0000-0001-7594-0564

${ }^{2}$ Одесский национальный политехнический университет, пр. Шевченко, 1, г. Одесса, 65044, Украина
}

\section{ЭНЕРГОЭФФЕКТИВНЫЕ ТРАНСФОРМАТОРЫ ДЛЯ ЭЛЕКТРОПОТРЕБИТЕЛЕЙ С РАЗЛИЧНЫМИ ГРАФИКАМИ НАГРУЗКИ}

Неучет при проектировании действительного режима работы (графика нагрузки) электропотребителя приводит к неэффективному использованию трансформаторной мощьности. Предлагается при неплотном графике нагрузки спроектировать трансформатор на ближайшую меньшую нормализованную мощность по сравнению с реальной загрузкой, при этом предусмотреть возможность интенсификаџии охлаждения при увеличении потребляемой мощности.

Ключевые слова: Трансформатор; Потребляемая мощность; Нагрузка; Вместимость; Распределительные сети.

\section{ЛИТЕРАТУРА}

1. Быстрицкий Г.Ф. Выбор и эксплуатация силовых трансформаторов. / Г.Ф. Быстрицкий // - М.: Издательский центр «Академия». - 2003. - 176 с.
2. ГОСТ 14209-97(МЭК 354-91). Межгосударственный стандарт. Руководство по нагрузке силовых масляных трансформаторов. (Дата введения 2002.01.01).

3. ДСТУ 3645-97 (ГОСТ 3484.2-88) (IЕC 600762:1993) Трансформатори силові. Допустимі переви- 
щення температури та методи випробування на нагрівання. - Чинний від 2000-07-01. - 35 с.

4. Зуев Э.Н. К вопросу об актуализации нормативов на экономическую плотность тока. / Э.Н. Зуев // Электро. - 2002. - № 6.

5. Кравченко А.Н. Масляные энергоэффективные трансформаторы. / А. Н. Кравченко, В.П Метельский - Электрик. - 2013. - № 5.

6. Матухно В.А. Проектирование оптимальных трансформаторов для различных эксплуатационных нагрузок / В.А. Матухно // - Електромашинобудування та електрообладнання. - 2009. - Вип. 73. C. $97-101$.

7. Пекелис В.Г. Определение оптимальных уровней потерь холостого хода и короткого замыкания для различных режимных условий работы трансформаторов мощностью до 1600 кВА / В.Г. Пекелис, Е.В. Мышковец, Ю.В. Леус // - Электро. - 2003. - № 1. C. 42-46.

8. Пуйло Г.В., Чайковский В.П., Матухно В.А. Серия оптимальних трансформаторов для электропотребителей с различными графиками нагрузки. Наука в інформаційному просторі : матеріали IX Міжнар. наук.-практ. конф., 10-11 жовт. 2013 р. : у 8 т. - Т. 3 : Технічні науки. - Дніпропетровськ, 2013. - 119 с. URL: http://www.confcontact.com/2013-nauka-v-informa tsionnom-prostranstve/tn6_pujlo.htm

9. Савинцев Ю.М., Карамутдинов Р.Н. Выбор силового трансформатора - дело серьезное [Электронный pecypc]. Режим доступа: http://www.energyland.info/ analitic-show-56794.
10. Тихомиров П.М. Расчет трансформаторов. Учебное пособие для вузов: издание пятое, переработанное и дополненное. / П.М. Тихомиров // - М.: Энергоатомиздат. $-1986 .-528$ с.

11. Шидловский А.К. Расчеты электрических нагрузок систем электроснабжения промышленных предприятий. / А.К. Шидловский, Г.Я. Вагин, Э.Г. Куренный // - М.: Энергоатомиздат. - 1992. - 224 с.

12. Энергосбережение в Европе: применение энергоэффективных распределительных трансформаторов [Электронный ресурс] /Издание Европейского института меди (Тема «В» совместно с Европейской Комиссией проекта № STR-1678-98-BE), пер. с англ. Е. В. Мельникова // - Энергосбережение. - 2004. - № 1. Режим доступа: http://www.abok.ru/for_spec/articles. php?nid $=2384$.

13. HD 428 (Harmonization Documents): Трехфазные распределительные трансформаторы с рабочей частотой 50 Гц от 50 до 2500 кВ·А с масляным охлаждением и максимальным напряжением не выше 36 кВ. [Электронный ресурс]. Режим доступа: http://www. abok.ru/for_spec/articles.php?nid=2384.

14. Стали и сплавы коррозионно-стойкие и специальные в Украине [Электронный ресурс. Режим доступа: http://www.ua.all.biz/stali-i-splavy-korrozionno-stojkie-ispecialnye-bgr1553].

15. Трансформаторные масла [Электронный ресурс]. Режим доступа: http://odessa.pulsen.com.ua/price/ 040119-transformatornye-masla].

Отримана в редакції 23.12.2015, прийнята до друку 03.03.2016 